\title{
Living in the senses and learning with love - John MacMurray's philosophy of embodied emotion
}

\section{James MacAllister, Malcolm Thorburn}

Abstract: In this article we analyse the central role that the body plays in John MacMurray's account of learning to be human. As with Merleau-Ponty, MacMurray rejected mind-body dualisms and argued for the need to understand what it means to be a person. Through our analysis we highlight the key principles that characterize MacMurray's philosophy in relation to personhood and the body, namely: 1) all human knowledge and action should be for the sake of friendship and 2) human persons exist first and foremost in their bodies as 'knowing agents' rather than in their minds as 'knowing subjects'. We thereafter explain MacMurray's views on education and how it must support people to live in personal rather than functional relation with each other by attending more to bodily experience and education of the emotions. Accordingly, MacMurray considered that persons can either 'use' their bodily senses as mere instruments for functional purposes or they can 'live' in their bodily senses by learning to love (not 'using' but rather apprehending the real value of) other persons. In conclusion, we suggest that MacMurray's philosophy can open up a different way of thinking about the educational value of physical activity. For MacMurray shared physical pursuits are especially educational when carried out for their own sake and when all persons' present experience moments of bodily joy and togetherness and a better understanding of each other.

Key words: senses, persons, agency, love 


\section{Introduction}

It is only in more recent times that the philosophical work of John MacMurray has begun to generate scholarly interest in the field of education ${ }^{1}$. We think this is rather surprising for at least three reasons. First, MacMurray wrote and spoke quite extensively and eloquently on the subject of education over the course of a long and distinguished academic career ${ }^{2}$. Second, he was personally involved in the running of two educational establishments informed by his philosophy of education. MacMurray served as chairman of the board of the progressively experimental Wennington School in Lancashire throughout its (35 year) existence until it closed in 1975. During this time he both acted as mentor and friend to the head teacher there, Kenneth Barnes, while also making financial contributions to the school. As Costello notes of MacMurray's involvement in Wennington: 'it was a clear instance of that rather rare event: putting one's energy and money where one's mouth was - for a lifetime' (2002, p. 374). MacMurray was also on the Executive Committee of Newbattle Abbey College from 1937-1956. Newbattle was a pioneering project in MacMurray's native Scotland intended to offer foundation courses in humanistic thinking to students who may not previously have had access to them - and in particular adults from working class backgrounds. While there turned out to be little appetite in Scotland at the time for such an institution, the Newbattle experience did cement in MacMurray's mind what he took to be the principal problem inherent in both education and wider society - the dominance of technicist and competitive imperatives over co-operative, humane and personal ones (MacMurray, 2012; Costello, 2002).

Which brings us to the third reason we find it surprising that there has been relatively little attention devoted to the educational views of MacMurray - we think that what MacMurray had to say on the state of play in education over 50 years ago is of continuing relevance today, perhaps especially in regards to the education of the body and the whole person. This article will therefore articulate the central role that the body plays in MacMurray's account of learning to be human and it will seek to tease out some possible points of relevance from Macmurray's philosophy to contemporary

1 See for example Pring, Facer, Stern, Cunningham, Noddings, Gaita and Fielding (all 2012) and Fielding (2006, 2007a and 2007b).

2 Costello (2002) notes that MacMurray collected together his own writings on education into book form in the early 1970's only for this manuscript to be rejected by Faber. For good examples of MacMurray's writing specifically on education see MacMurray (2012, 1964). 
physical education. The argument unfolds in three phases. We firstly highlight the key principles that characterize MacMurray's philosophy of the personal, namely: 1) all human knowledge and action should be for the sake of friendship and 2) human persons exist first and foremost in their bodies as 'knowing agents' rather than in their minds as 'knowing subjects'. We secondly show how MacMurray considered that persons can either 'use' their bodily senses as mere instruments for functional purposes or they can 'live' in their bodily senses by learning to love (by apprehending the real value of) what is other than them (especially other persons). We thirdly explain MacMurray's views on education and how it must support people to live in personal rather than functional relation with each other by attending more to bodily experience and education of the emotions. In the process we review some possible implications for education of MacMurray's theory of embodied emotions, and in particular, how it could challenge educators to reconsider the value and purposes of their practices.

\section{John MacMurray's philosophy of personal life}

'Personal life...in distinction both from the individual and social life...is the life which we live as persons, and we can live it only by entering into relationships with other people on a fully personal basis, in which we give ourselves to one another; or, to put the same thing the other way round, in which we accept each other freely for what we are' (MacMurray, 1961, p. 101).

John MacMurray's philosophy was centrally concerned with addressing the question of what it means to be a person. In Persons in Relation (1961b) MacMurray explained why he chose to give his philosophical attention to the concept of the personal rather than personality. He felt that the latter term had become almost synonymous with the individual characteristics that differentiate one person from another (personal individuality), rather than the set of essential attributes that are common to all people and make each person a person. It was the latter issue of what it means to be a person, rather than what it is that makes us individual persons, that most interested MacMurray. One of the first attempts he made to address the meaning of human personhood can be found in his lecture on The Personal Life, which is published in Reason and Emotion (1961), a book that contains a number of other public lectures he delivered for radio broadcast in the 1930's and 1940's. In this lecture he explained that 'we must be clear about what is meant by personal life. It is the life we lead as human beings' (MacMurray, 1961, p. 93). However, MacMurray recognised that equating the personal life with the human one was rather platitudinous without further elabora- 
tion. He therefore sought to distinguish personal life from both individual life on the one hand, and social life on the other. MacMurray felt that the tendency to contrast individual and social life was a misleading and unhelpful one - particularly if social life is construed (and he felt it often was) as a series of obligations towards, and restrictions imposed upon, our individual existence by wider society. He therefore stressed that the 'personal life is not the life that we live in solitude, when there is nobody to interfere with our personal preferences and prejudices' (ibid, pp 95-96). Instead he argued that the personal sphere does not refer to our individual wants and desires at all - it is rather composed of human relations between people.

However, MacMurray was also adamant that the sets of human relations that characterise personal life are very different from, and much richer than, merely social relations. This is so as social relationships presuppose, as a matter of fact, a degree of impersonality (MacMurray, 1961). Social life for MacMurray frequently depended upon people involving themselves in impersonal relations with others - impersonal as persons enter into such relations not with the whole of themselves but only with part of themselves. However, just because we cannot always express the whole of our personhood in all of our interactions with others, does not mean that we can only be ourselves when we are alone - far from it. Indeed, for MacMurray, 'to be ourselves at all, we need other people' (ibid, p. 97). MacMurray is even more emphatic about this in Persons in Relation where he argues that there can be no person whatsoever, without two persons in communication. Thus personal life can be distinguished from individual life on account of the fact that we need the presence of others (albeit in a particular way) to be persons at all. Importantly, personal life can also be differentiated from social life on account of the onus distinctively personal relations place upon us to express our whole selves to others, as opposed to only parts of ourselves (as is required in merely social relations). As MacMurray puts it: 'the personal life demands...a relationship with one another in which we can be our whole selves and have complete freedom to express everything that we are' (ibid, p. 97). Moreover, the personal life not only requires a full of expression of who we are to others, it also necessitates a loving acceptance of others when they express the whole of themselves to us. And MacMurray allots a name for such open, expressive and accepting relations between persons - friendship. He articulates this as follows: 'friendship is a type of relationship in which people enter as persons with the whole of themselves' (ibid, p. 101).

MacMurray specifies that the sorts of friendships that make up the personal life have no ulterior motive beyond the personal interaction itself. He explains 
that there are two opposing varieties of relations with others: functional relations where we fraternize with others merely to achieve some other purpose, and personal relations, which we enter into without extrinsic purpose. Personal relations come to exist for their own sake and for the sake of our friends, rather than our selves. It is not a genuine friendship and personal relation if two persons only relate with each other merely to get something else out of it (MacMurray, 1961, 1961b) - such associations are functional as the purpose of the relation is determined by a function external to it. Real friendships in contrast have no external function. They are instead founded upon a motive of love for the other and a desire to get to know the other person better and see them flourish in the world more. MacMurray eloquently expresses it like so: 'when you love anyone you want above all things to be aware of him, more and more completely and delicately. You want to see him and hear him, not because you want to make use of him but simply because that is the natural and only way of taking delight in his existence for his sake. That is the way of love and it is the only way of being alive' (MacMurray, 1961, p. 42).

While MacMurray does not dispute that a prosperous society in part depends upon functional relations, he emphasises that the value of functional interactions should be measured by the extent to which they further distinctively personal relations. For MacMurray both individual and social life should be subordinate to, and for the sake of, personal life. Indeed, all human association 'has only one meaning...it is the necessary foundation on which the personal life can be built. Society exists for the life of personal friendship' (ibid, p. 102). MacMurray goes as far to suggest that all of morality depends upon our capacity to prioritise personal over functional relations (1961) while in both the Self as Agent and Persons in Relation, MacMurray explicitly argues that all human knowledge and action should be for the sake of friendship. The distinctively personal life is therefore one where the establishment and maintenance of fully expressive and accepting friendships takes precedence over all other priorities and where all feeling, thought and action must ultimately nurture and sustain such friendships. Indeed, we think that this is the first and fundamental principle of MacMurray's philosophy. We think that the second fundamental principle of MacMurray's philosophy is that in the distinctively personal life that prioritises friendship, personal existence is experienced first and foremost in the body rather than in the mind. As we shall see later in the paper, this view of personhood, as being lived in and through the body, carries with it significant educational implications. 


\section{The crisis in personal life}

MacMurray was in the first place motivated to articulate a philosophy of the personal because he felt that there was a crisis in 'personal life' brought about by the revolutionary economic and technological changes that emerged in the twentieth century $(1956,2012)$. There were, he said, two key indicators for this crisis of the personal: 1) the decline of the influence of religion in personal life and 2) the growth in the influence of the state and technology in personal life (1956). The increasing appeal to political authority not only evidenced an increasing unwillingness for people to assume personal responsibility for their own actions; it also fuelled the growth and reach of the state to the extent that the personal aspect of human life was now being subsumed within and dominated by the functional aspect of human life (MacMurray, 1956). MacMurray concluded that the form of the personal was thus the emergent social problem of the twentieth century and as such should be the emergent problem considered by philosophers of that era too. Indeed, MacMurray thought that other developments in twentieth century philosophy, including phenomenology, existentialism, and logical empiricism were also in no small part a response to this personal crisis (1956). However, he did not think that either existentialism or logical empiricism had adequately responded to the personal crisis. Nor did he think that the dominant Kantian/Descartesian tradition in western philosophy had within it the resources to respond to the personal crisis either (MacMurray, 1956). While existentialism had rightly identified that philosophy needed to focus its attention upon the very real and human problems like despair and anxiety in the face of global warfare, existential writing was for MacMurray expressed in such an aesthetic style that it had abandoned philosophical form altogether. Logical empiricism in contrast retained philosophical form and style while retreating further and further from the practical problems of human life in favour of metaphysics (MacMurray, 1956).

There can be little doubt however that MacMurray thought that phenomenology was the branch of new philosophy best placed to grapple with the emergent crisis in personal life for he stated that 'phenomenological analysis is a useful device' (MacMurray, 1956, p 28) that we should be grateful for, when considering the limitations in the western philosophical tradition ${ }^{3}$. In this respect, MacMurray, like phenomenologists such as Merleau-Ponty, rejected mind-body dualisms and thought that we must try to better

\footnotetext{
3 MacMurray is also said to have delivered a series of five lectures on the "phenomenology of the personal' in 1929, though the materials that formed the content of these lectures has never been found (Costello, 2002).
} 
understand what it means to be a person. Importantly MacMurray, like Merleau-Ponty also thought that the philosophy of Kant and Descartes had mistakenly downplayed the significance of the body in human life. Though MacMurray did consider full personhood to be impossible without others, he did not question the fact that individual selves could and most often did exist in isolation. Indeed, the Self as Agent (1956) is a text devoted to understanding the nature of the existence of the self in isolation. In this treatise, MacMurray sought to challenge what he considered to be the theoretical and egocentric presuppositions apparent in the modern philosophical account of selfhood advanced by Kant and Descartes. MacMurray did so by articulating an in depth account of the self, conceived of as an active, communal and relational agent rather than an egocentric, knowing and withdrawn individualistic subject $(1956,1961 b)$.

In MacMurray's philosophy human agency signifies a capacity to act in the world and so influence and change the world. In contrast human subjectivity signifies a withdrawal from the world of action and sensory experience into one of pure thought and intellectual reflection. Significantly, MacMurray maintained that selves are agents first and subjects second (1956). In taking this stance he effectively called for the primacy of practical rather than theoretical life for human persons. MacMurray felt that the crisis in personal life had reached such dehumanizing proportions that it was no longer viable to retreat from it, into thought, and so construe the self as 'the subject in experience, and so as knower. The self must be conceived not theoretically as subject, but practically, as agent' (MacMurray, 1956, p. 38). MacMurray proposed that the Cartesian/Kantian mind and body dualism must be rejected through the assertion of the 'primacy of the practical'. By this he meant the substitution of the 'I think' with the 'I do' as the starting point for philosophy. MacMurray not only called for philosophy to take practical life as its focus over theoretical life though, he ultimately thought that human behaviour, thought and action could only be properly understood from a personal, active and bodily perspective. MacMurray, thought that human selves exist first and foremost in their bodies as agents rather than in their minds as subjects.

\section{The person as knowing agent in the body}

MacMurray argued that philosophy had to abandon its positioning of the self as thinker in isolation (as in the Kantian/Descartesian tradition) and instead give due recognition to the necessarily bodily and personal nature of human action and thought. He states that if in any sense, the fact that 
I am thinking proves - or should we say presupposes - my existence, then it certifies my existence not as a mind, but as a body (1956, p. 81). It is not then thought divorced from the body that confirms a person's existence (as in the modern tradition) but rather thoughtful action, in the body. MacMurray maintained that acting is not free from, but is rather always infused with thought. Indeed he argued that we always act with knowledge - it is mere movement that is devoid of thought. He stated that 'knowledge is that in my action which makes it an action and not a blind activity' (ibid, p. 127). MacMurray argued that action always occurs in the material world whereas (pure) thought involves a temporary reflective removal of the self from the material world. By retreating into thought and removing the possibility of material action one makes ones self a subject. MacMurray though reasons that as nothing can be acted on that is not material, the self as agent must be material - the self as subject must in contrast be non-material. 'As Agent, therefore, the Self is the Body. Conversely, the Self, as subject, is the mind... as subject the Self is non-agent, withdrawn from action, and, therefore, non-body' (ibid, p. 91). MacMurray thus argues that human agency entails knowing action in the material world whereas human subjectivity entails a reflective withdrawal from action in the world.

Furthermore MacMurray insists that human persons exist first and foremost in their bodies as 'knowing agents' rather than in their minds as 'knowing subjects'. While MacMurray thought it impossible to be both agent and subject at one and the same time he did not think the self was somehow divided in two - between action on one hand and thought on the other. Rather it is the same self that acts and thinks at different moments and simultaneously. MacMurray emphasised that persons both act and think in their bodies and that the mind/body dualism instantiated by Descartes and Kant was therefore fictitious ${ }^{4}$. Acting and thinking are rather contrary limits on personal experience where 'acting is the positive, while thinking is the negative limit (ibid, p. 87)'. Importantly thinking is negative because it negates the possibility of concrete worldly action while excluding a wide range of bodily experiences as well (MacMurray, 1956). Action however is an inclusive concept because it does not exclude bodily sensations. While action is primary and concrete and enmeshed with this world, thought is secondary and derivative and in important respects removed from this world. $\mathrm{He}$ explains this relation as follows:

4 Harrison (2002) also agrees that MacMurray especially sought to challenge what (he took to be) Kant's failure to present a unified account of the self. MacMurray held that Kant was unable to explain how the same self exists in both the theoretical and practical spheres of life (MacMurray, 1956; Harrison, 2002). 
'In thinking the mind alone is active. In acting the body is indeed active, but also the mind...When we act, sense, perception, and judgment are in continuous activity along with physical movement. When we think, we exclude overt bodily movement at least...the 'purer' our thought becomes the more it excludes not merely perception, but all the sensuous elements, and moves in a shadowy world of abstract and general ideas. Action, then, is a full concrete activity of the self in which all our capacities are employed; while thought is constituted by the exclusion of some of our powers and a withdrawal into an activity which is less concrete and less complete.' (MacMurray, 1956, p. 86)

MacMurray emphasises then that the self is realised most fully in action rather than pure thought - the self is therefore essentially an agent that is able to act in and change the world rather than a subject who stands back from and thinks about the world. What distinguishes the self as agent and the self as subject is the capacity to effect change in the world and so determine the future. Through acting, persons generate or 'bring into existence' an actuality or possibility - to act is to determine a possibility (MacMurray, 1956). Furthermore, action involves thought and 'choice' for MacMurray a choice to generate a present possibility in this way rather than that and so (with time) determine the past in this way rather than that. MacMurray stressed that action is not preceded by choice but is choice - 'the actual choice is the doing of the action' (ibid, p. 140). However, MacMurray argued that only the past is wholly determinate. While we can predict what the future might look like and consist of, a determinate future is not a 'real' future (MacMurray, 1956).

In our view, the notion of the future as indeterminate, until human persons make choices through action, is central to MacMurray's concept of agency. MacMurray argued that persons are only really agents able to change the future shape of the world before them, if they really are free to shape the world before them (1956). If all actions were determined in advance then human beings would be predetermined objects rather than free agents (MacMurray, 1956). Importantly MacMurray thought it was morally necessary for all persons to be conceived of as free agents able to actively and consciously alter the world around them rather than subjects (who think about the world) or objects (we use in the world). To explain his reasoning on this point he indicates that in a social world the actions of others do, as a matter of fact, limit the possibilities of my own action (MacMurray, 1956). However, to consider the actions of others as a mere limit upon my own, would be to fall into the mistaken functional understanding of human relations (where soci- 
ety merely limits individual desire and behaviour) discussed in the second section of this paper. For MacMurray meaningful personal interactions with others hinge on understanding that others are much more than limiters of my choice, or objects to be used. As we shall see in the next section, though MacMurray thought we exist first and foremost in our bodies as knowing agents, he also held that existence only becomes meaningful when we learn how to step outside the isolation of our individual bodily experience and into personal rather than functional relations with others.

\section{Living in the senses and learning with love}

'We have to learn to live with the whole of our bodies, not only with our heads. If we do this, we shall find ourselves able to act in the world' (MacMurray, 1961, p. 45)

Two principles appear to underpin MacMurray's philosophy of education - namely that: 1) education must support people to live in personal (rather than functional) relation with each other by 2) attending more to bodily sense experiences and education of the emotions ${ }^{5}$. In his lecture on Learning to be Human, MacMurray asserts that 'the first priority in education - if by education we mean learning to be human - is learning to live in personal relation with other people...I call this the first priority because failure in this is fundamental failure, which cannot be compensated for by success in other fields' (MacMurray 2012, p. 670). MacMurray (1956, $1960,1961,2012)$ suggests that people first live as individuals rather than as persons. Individuals are characterized by a dependence on others and by egocentricity. In contrast, persons are characterized by their capacity to live in interdependent relation with others. Fostering personal relationships should be the primary task of education for MacMurray because it is through such relations that persons can successfully overcome the human predilection to egocentricity. MacMurray felt that education fails when persons take their own feelings and interests to be more important than those of others. He also maintained that emotion education holds the key to educational success and to the transcending of the human tendency towards dependence and egocentricity. Indeed, an enhanced concentration on the education of bodily sensibility is the second educational priority specified by MacMurray (2012, p. 671).

5 Fielding $(2006,2007)$ also takes the development of personal rather than functional relations to be at the core of MacMurray's educational philosophy. Fielding elsewhere (2012) alludes to the centrality of emotional education in any Learning to be human. 
MacMurray maintained that our bodily senses (rather than our minds), are the gateway to the world outside of us - they are the primary source of all knowledge $(1956,1961,2012)$. He indicates that persons can gain knowledge through their senses in two ways. On the one hand human senses can be used as instruments to provide facts about the world, which can in turn be used to solve practical and instrumental problems. Here our senses are used in a thin and functional way. On the other hand persons can live in their senses, by construing their sensory experiences not as means to practical ends and problem resolution, but rather as ends in themselves. Here our senses are not so much used but lived in a personal way. Though people generally use their senses for functional reasons (MacMurray, 2012) the real value of sense experience is rather to be found within personal rather than functional life. This seems to be why MacMurray thought education should seek to foster thick and personal emotional experiences rather than thin and functional ones (MacMurray, 1961, 2012). The thick living in sense experience entails coming to really know what is other than the self, as a thing in itself: as something that exists in its own right, as something that is more than object to be used for mere instrumental purpose. Thus while MacMurray thought we must live in and learn through our own bodies, he was not advocating a self-absorbed dwelling in, and focus on, one's own bodily feelings - such an attitude would be functional rather than personal.

Bodily sense experiences only become intrinsically valuable and personal when they are contemplative and objective. Contemplative and objective sense experiences are both directed at objects or persons other than the self and concerned to apprehend more fully the value of what is other than the self. He states that 'contemplation when it is genuine centres our attention and interest upon something outside of us, and so is a powerful counteraction to the egocentricity which keeps us juvenile and adolescent. It centres our emotional capacities upon the object in a search for its uniqueness and reality; and so provides an emotional objectivity for the apprehension of its value. So contemplation is a powerful agent for the education of the emotions' (MacMurray, 2012, p. 672). MacMurray adds that if contemplative sense experiences are not cultivated in education then 'our emotional nature remains...crude and childish' (ibid, p. 672). He maintained that people are generally inclined to perceive the world in a self-centred and immature way where one's own interests and desires are deemed to be more important that those of others. However, he argued that educated persons have learned to focus their sensory attention upon others in an open and accepting spirit and with a desire and capacity to act with and for the other person in a way 
that helps them grow. MacMurray suggests that living in ones senses in this way enables persons to learn with others through love: he states that living through the senses is living in love' (1961, p. 42).

Education of bodily sense experience thus reveals itself to be vital to MacMurray's theory of learning to become a person because the senses are the means by which persons can learn about the world outside of their own ambitions. And it is by living in ones senses and learning about the world beyond their individual selves that persons mature, through love. MacMurray appears then to have thought that living in the senses and with the whole of our bodies made meaningful and loving action possible - and as we learned in the second section of this paper, he thought that all meaningful human knowledge and action ought to be for the sake of friendship. We thus think that in MacMurray's philosophy, education should cultivate in person's an ability to express the whole of themselves to others through their bodies as well as an ability to pay loving attention to what our bodily senses reveal to us about others. Given the emphasis his philosophy places on bodily expression and in learning in and through the body, we think it is surprising that physical educationists have not to date shown any interest in MacMurray. We therefore consider the prospects for a MacMurryian philosophy of physical education in the final section of this paper - and in particular how such a theory might challenge physical educators to reconsider the purposes of their pedagogical practices.

\section{The prospects for a MacMurryian philosophy of physical education}

We think MacMurray's philosophy of the personal can shed new light on a recurring theme in the history of physical education - namely, the debate around the relative educational merit of different types of physical activity and in particular, the different gains or otherwise associated with team games on the one hand and individual activities on the other. In this respect, we think it is important to question again and from different perspectives, the value of such activities as views concerning the value of team games and individual activities may not have moved on so very much since 1800. As Kirk (2010, p. 3) notes in recalling histories of physical education from the late 1800s onwards, the subjects 'differences are for the most part less significant than the similarities'. In Scotland, it was the visionary and reformer, Hely Hutchison Almond, who as Headteacher of Loretto School, pioneered in the late 1800s the notion that team games (rugby in particular) could absorb the enthusiasm and energies of pupils and contribute to 
the 'achievement of the kind of proper manliness that parents and teachers desired' (Holt, 1989, p. 89). However, while team games could cultivate shared team spirit and educate pupils how to lose well and win with dignity, Almond disliked individual sports (such as athletics) as they compromised the collective ethos and sense of fair play that team games could foster (Mangan, 2010). Later an ex Loretto pupil under Almond, Robert Mackenzie became Headteacher of Edinburgh Academy and he introduced programmes of games and physical training that where 'no more than the application of Almond's ideas to the problems of day-school life' (Mackenzie, 1906, p. 243). Mackenzie's school arrangements were praised by government inspectors and influenced the recommendations of the 1903 Report of the Royal Commission on Physical Training (Scotland) where it is noted that we consider that a necessary element in a liberal education of every citizen is a sound system of physical training' (p. 12).

Influenced in many instances by the lack of playing spaces available, the version of physical training enacted in the first half of the twentieth century was often a Swedish form of gymnastics that emphasized individual discipline and precision in the way free standing movements were completed. The goal was to aid good posture and physical development rather than cultivating personal growth (Kirk, 2010). By the middle part of the twentieth century Swedish gymnastics was overtaken by the type of activities Almond would have valued; as Olympic gymnastics and games teaching became an established part of school life. Games were advocated on the basis of being a universal good for all pupils, and among the challenges this raised was how can games teaching avoid reproducing social and gender inequalities. In recent decades related enquiry has often taken the form of reviewing the value of sport education programmes in physical education. Sport education has a focus on developing pupils' personal-social needs, through supporting inclusion and building social connections (e.g., team affiliation, shared communication and decision-making) between pupils as well as promoting individuals psychomotor competence and wider affective development. Perlman (2011, p. 89) found, for example, that consistently playing in the same team plus applying the standardized use of fair play guidelines helped 'create a sense of belonging and enhanced inclusionary feelings'. However, the architect of sport education (Daryl Siedentop) in his text on this new teaching approach (Siedentop, 1994) largely focused on the pragmatics of planning pupils learning experiences rather than elaborating on educational values and how they might underpin and be realized through sport education. 
In most of these developments over the last century, we consider that Macmurray's writings have something of importance to add. While many accounts of the educational value of individual and team games have historically tended to variously identify instrumental, functional and/or competitive and individualistic imperatives like a disciplined body, enjoyment in winning and losing or team spirit, MacMurray's philosophy stresses the value of more distinctively personal goals. Indeed his view that living in ones body can be educationally valuable on account of the close expressive and accepting friendships that might become possible through shared physical activity does we think open up a different way of thinking about the value of physical activity. Macmurray's writing would, for example, endorse, the view that competitive individual activities like tennis cannot be classed as genuinely educational unless serious attention is given to supporting pupils to play in ways where there is an emphasis on cultivating a fully expressive and personal interaction with the other participants rather than an overarching desire to beat opponents. Similarly, reference to Macmurray would also highlight that while a game like rugby may afford opportunities for teammates to develop fully expressive and accepting friendships with their teammates (or perhaps even members of the opposition), if winning the game is the goal that unites the teammates then it is probable that the interactions in question are, in themselves, social and functional in nature rather than educational and personal. Again, Macmurray's writings would support an elaboration of how the contribution of programmes like sport education, could if enacted with suitable care and pedagogical sensitivity, connect bodily experiences with the development of related friendship goals.

A further possible benefit of Macmurray's contribution is that it might challenge educators to review the aims and teaching approaches adopted on physical education programmes. For example, studying Macmurray's educational writings at the height of Swedish gymnastics popularity in schools would have made it easier to detect that the educational virtues being advanced in terms of self-discipline and obedience were often being overtaken by the needs of institutional order, where 'transgression meant certain and often brutal punishment' (Kirk, 2010, p. 72). This is something Macmurray would have abhorred. Furthermore, in current times, Macmurray's thought highlights the need to review how individual activities can move beyond being unduly self-absorbed and narrow in their focus. Encouragingly, writers in the field are, from a mostly Merlau-Pontian perspective at present ${ }^{6}$, beginning to

6 For recent discussion of the work Merleau-Ponty and/or phenomenology in relation to physical education see Thorburn (2008), Martínková I., \& Parry J. (2011) and Stolz (2013). 
review how bodily experiences can help persons better understand and make meaning from their own lives and those of others. This dual emphasis on the bodily experiences of self and others is helpful, as we would argue that there is a case to be made for meaningful engagement in routine physical activities which are pursued together, especially relative to the priority there often is nowadays in physical education to emphasize the importance of lifelong physical activity. In a MacMurrayian theory of embodied learning though, it has hopefully become clear that the primary criterion of any activities' educational value is that it promotes personal relations rather than mere individual cognitive or emotional development or lifelong physical activity.

A shared cycling venture into a rural and hilly part of the country might be an example of such a joint activity. While the solitary cyclist may feel great joy in breathing in the country air and accrue cardiovascular and muscular benefits from the exercise, the activity only really begins to take on its full meaning in a MacMurrayian account if the person can take the bodily joy and benefits they feel back into their personal life and in a way that makes some of their friendship relations more rich. Thus a given embodied action only becomes educationally meaningful for a person when it is carried out in the knowledge that its ultimate value is dependent on the extent to which it enables them to better foster genuinely open personal relationships with others. We happen to think that a physical activity like solo cycling can provide a physical, cognitive and emotional space that better prepares one to relate more fully with others. However, there can be little doubt that a shared cycling activity would be preferable in a MacMurryian theory of embodied learning especially if all persons' present experience moments of bodily joy and togetherness in the venture and a better understanding of each other.

Some might therefore consider that a MacMurrayian philosophy of physical education is somewhat limited in respect to meaning making in and through the individual bodily self, as he does generally stress that the types of experiences that can be deemed personally enriching and worthy of educating are those that focus on the other rather than the self. However, we consider that this is probably not the case, particularly with regard to Macmurray's writing on the benefits of expressive activities such as dance. For MacMurray dance is an activity of real educational possibility as it invites persons to act with the whole of themselves in an emotionally alive, bodily and personally responsive way (MacMurray, 1956). When persons feel and move in their bodies with joy and a better understanding of others then that activity begins to become educationally meaningful for MacMurray. More broadly then we believe that MacMurray's philosophy can challenge educationists (educationists in gen- 
eral and physical educationists especially) to think again about the importance of learning together in and through the body and in a non-egocentric manner. For MacMurry shared physical pursuits are especially educational when carried out for their own sake and when all persons' present undergo moments of bodily joy and togetherness and a better understanding of each other. If his philosophy does go too far in denouncing all self-focused bodily experiences as meaningless unless they in the end promote a love of other persons too, it does perhaps at least encourage persons to think about how often they actually do engage in physical activities to learn of and with others and for their sake at least as much as their own. In summary, we consider that MacMurray's philosophy of education can, despite its possible limitations, provide an original way of explaining the educational value of bodily experiences which can promote friendship and a focus upon the prospering of the other rather than (or at least as much as) the self. We think education promotes such experiences all too rarely.

\section{References}

Costello, J. (2002). John MacMurray: A biography. Bristol: Floris Books.

Cunningham, P. (2012). John Macmurray's learning to live and the new media, 19311949: learning for labour or leisure? Oxford Review of Education, 38(6), 693-708.

Facer, K. (2012). Personal, relational and beautiful: education, technologies and John Macmurray's philosophy. Oxford Review of Education, 38(6), 709-725.

Fielding, M. (2006). Leadership, radical student engagement and the necessity of person-centred education. International Journal of Leadership in Education, 9(4), 299-313. Fielding, M. (2007). The human cost and intellectual poverty of high performance schooling: radical philosophy, John Macmurray and the remaking of person-centred education. Journal of Education Policy, 22(4), 383-409.

Fielding, M. (2007a). On the necessity of radical state education: Democracy and the common school. Journal of Philosophy of Education, 41(4), 549-557.

Fielding, M. (2012). Education as if people matter: John MacMurray, community and the struggle for democracy. Oxford Review of Education, 38(6), 675-692.

Fielding, M., \& Moss, P. (2011). Radical education and the common school: A democratic alternative. London: Routledge.

Gaita, R. (2012). Love and teaching: renewing a common world. Oxford Review of Education, 38(6), 761-769.

Harrison, S. (2002). MacMurray and the Mind-Body problem revisted. In D. Fergusson \& N. Dower (Eds.), John MacMurray: Critical perspectives (pp. 51-67). Oxford: Peter Lang.

Holt, R. (1989). Sport and the British: A modern history. Oxford: Clarendon.

Kirk, D. (2010). Physical education futures. London: Routledge.

MacAllister, J. (2013). The 'physically educated' person: Physical education in the philosophy of Reid, Peters and Aristotle. Educational Philosophy and Theory, 45(9), 908-920. 
Mackenzie, R. (1906). Almond of Loretto. London: Constable.

MacMurray, J. (1956). The self as agent. London: Faber and Faber.

MacMurray, J. (1960). Persons in relation. London: Faber and Faber.

MacMurray, J. (1961). Reason and emotion. London: Faber and Faber.

MacMurray, J. (1964). Teachers and pupils. The Educational Forum, 39(1), 17-24.

MacMurray, J. (2012). Learning to be human. Oxford Review of Education, 38(6), 661-674.

Mangan, J. (2010). Almond of Loretto: Scottish educational visionary and reformer. The International Journal of the History of Sport, 27(1-2), 296-307.

Martinková, I., \& Parry, J. (2011). An Introduction to the phenomenological study of sport. Sport, Ethics and Philosophy, 5(3), 185-201.

Merleau-Ponty, M. (1962). The phenomenology of perception. London: Routledge.

Noddings, N. (2012). The caring relation in teaching. Oxford Review of Education, 38(6), 771-781.

Perlman, D. (2011) Examination of self-determination within the sport education model. Asia-Pacific Journal of Health, Sport and Physical Education, 2(1) 79-92.

Pring, R. (2012). Putting persons back into education. Oxford Review of Education, 38(6), 747-760.

Pugmire, D. (1998). Rediscovering emotion. Edinburgh: Edinburgh University Press. Reid, A. (1996). Knowledge, practice and theory in physical education. European Physical Education Review, 2, 94-104.

Report of the Royal Commission on Physical Training in Scotland. (1903). Volume I: Report and Appendix. Volume II: Minutes of Evidence and Index. Edinburgh: HMSO. Siedentop, D. (1994). Sport education: Quality PE through positive sport experience. Champaign, IL: Human Kinetics.

Stern, J. (2012). The personal world of schooling: John Macmurray and schools as households. Oxford Review of Education, 38(6), 727-745.

Stolz, S. (2013). Phenomenology and physical education. Educational Philosophy and Theory, 45(9), 949-962.

Thorburn, M. (2008). Articulating a Merleau-Pontian phenomenology of physical education: The quest for active student engagement and authentic assessment in high-stakes exami- nation awards. European Physical Education Review, 14, 263280.

Thorburn, M., \& MacAllister, J. (2014). Dewey, interest and well-being: Prospects for improving the educational value of physical education. Quest, 65 (4), 458-468.

\section{Authors:}

James MacAllister, Dr.

University of Stirling

School of Education

Pathfoot Building, Room A32

Stirling

FK94LA

Scotland

Email: j.w.macallister@stir.ac.uk 
Malcolm Thorburn, Dr.

University of Edinburgh

College of Humanities and Social Sciences

Moray House School of Education

St Leonard's Land

Holyrood Road

Edinburgh EH8 8AQ

Scotland

email: Malcolm.Thorburn@ed.ac.uk 